УДК 334.722.012.61-022.51/-022.55:330.341.1

JEL Classification: M 200, 0110

\author{
(C) Ткач С. В., Ткач С. В., 2021 \\ e.tkach@chnu.edu.ua, tkach.s1987@gmail.com \\ Чернівецький нащіональний університет імені Юрія Федьковича, Чернівиі
}

\title{
СОЦІАЛЬНО ВІДПОВІДАЛЬНИЙ ТА ІННОВАЦІЙНО АКТИВНИЙ ВЛАСНИЙ МІКРО-, МАЛИЙ ТА СЕРЕДНІЙ БІЗНЕС ЯК ОСНОВА ЕКОНОМІЧНОГО РОЗВИТКУ
}

Здійснено дослідження впливу сочіально відповідального та інноваџійно активного власного мікро-, малого $і$ середнього бізнесу на розвиток економіки, становлення громадянського суспільства й добробут людей. Зазначено, щу національний бізнес може бути достатньо ефективним, а економічний розвиток держави - сталим тільки за умови, якщэо підприємницький сектор: а) інноваційно активний; б) соціально відповідальний.

Ключові слова: власний мікро-, малий й середній бізнес, інноваційно активний бізнес, сочіально відповідальний бізнес, неформальні інституції, ментальність, навчальний курс, бізнес-ідея, стартап, інфраструктура підприємництва, фінансування бізнесу.

Постановка проблеми. Основу становлення та розвитку будь-якої економіки і громадянського суспільства загалом формує соціально відповідальний та інноваційно активний власний мікро-, малий i середній бізнес. У сучасному світі закономірністю (макроекономічною аксіомою) $\epsilon$ те, що економіка може розвиватись тільки за умови, що вона інноваційна та соціально зорієнтована. До основних характерних ознак соціально зорієнтованої ринкової економіки належать: досягнення високого показника середнього рівня доходів і заробітних плат громадян держави, вдосконалення системи соціального страхування та соціальних гарантій, розвиток акціонерних форм господарювання (насамперед міноритарного акціонування) i формування сектору малого бізнесу, передусім інноваційно активного. Бізнес, який упроваджує інновації, переважно отримує більші прибутки та забезпечує вищу динаміку економічного зростання.

Очевидно, що високий рівень доходів (отриманий у тому числі за рахунок таких джерел, як прибуток від підприємницької діяльності й дивідендні, пайові та процентні доходи від участі громадян у власності бізнесу) i заробітних плат - це важлива умова зростання платоспроможного попиту, збільшення заощаджень як джерела зростання інвестицій, розширення бази оподаткування та зростання бюджетних надходжень. Усе це у сукупності стимулює розвиток економіки держави. Водночас в Україні ми спостерігаємо прямо протилежні тенденції: зниження рівня доходів, слабкий розвиток акціонерних форм господарювання, наявність дефіциту такого надважливого ресурсу для економіки, як підприємницькі здібності, зменшення інноваційної активності суб'єктів господарювання. Досі на достатньому рівні не вдалося досягти усвідомлення громадянами держави, владою i суспільством загалом необхідності побудови соціально зорієнтованої інноваційної ринкової економіки.

Аналіз останніх досліджень і публікацій. Аналізу теоретико-методологічних основ розвитку соціально відповідального та інноваційно активного малого бізнесу присвятили свої праці відомі вітчизняні науковці: I. Бабець [1], Р.Бойчук [2], О. Дикань [4], Г. Камінчан [5], Л. Калініченко [6], О. Полякова [12] й ін. Проблеми державної політики щодо підприємств малого й середнього бізнесу розглядаються в дослідженнях А. Гальчинського, К. Васьківської [3], О. Касьяна [7], В. Компанійця [8], А. Ступки [13] та інших учених.

Виділення не розв'язаних раніше частин загальної проблеми. На сучасному етапі наявні численні напрацювання теоретичного та практичного характеру в цій сфері дослідження, але окремі питання, що стосуються надання практичних рекомендацій щодо стимулювання розвитку соціально відповідального та інноваційно активного власного мікро-, малого і середнього бізнесу, недостатньо розкриті у науковій літературі.

Формування цілей статті. Мета цієї статті $\epsilon$ визначення впливу соціально відповідального та інноваційно активного власного мікро-, малого і середнього бізнесу на економічний розвиток держави та розробка практичних пропозицій з чітким комплексом заходів щодо стимулювання його розвитку в Україні. 
Виклад основного матеріалу дослідження. За підсумками 2020 р. ВВП в Україні становив 142,2 млрд. дол., а ВВП на душу населення 3425 дол. США [11].

Водночас за той же період ВВП країн членів ЄС дорівнює 18000,0 трлн. дол., а ВВП на душу населення - 36000 дол.; ВВП США - 20807,2 трлн. дол., ВВП на душу населення - 63051 дол.;
ВВП Канади - 1600,2 трлн. дол., ВВП на душу населення - 42080дол.; ВВП Японії - 4 910,5 трлн. дол., ВВП на душу населення - 39048 дол. [11].

Усе це зумовлює наявність більшої кількості робочих місць, коштів на розвиток інфраструктури й соціальної сфери загалом, відповідний розмір заробітних плат і пенсій та ін.

Таблиия 1

\section{Макроекономічні показники України порівняно з показниками країн членів СС} та інших країн у 2020 p.

\begin{tabular}{|c|c|c|c|}
\hline Країни & ВВП, млрд. дол. США & $\begin{array}{l}\text { ВВП на душу населення, } \\
\text { дол. США }\end{array}$ & $\begin{array}{l}\text { Середній рівень } \\
\text { заробітної плати, дол. } \\
\text { США }\end{array}$ \\
\hline Україна & 142,25 & 3425,0 & 506,0 \\
\hline $\begin{array}{lll}\begin{array}{l}\text { Країни } \\
\text { (загалом) }\end{array} & \text { члени } & \text { СС } \\
\end{array}$ & 18000,0 & 36000,0 & 2574,0 \\
\hline США & 20807,27 & 63051,0 & 3632,0 \\
\hline Канада & 1600,26 & 42080,0 & 3444,0 \\
\hline Японія & 4910,58 & 39048,0 & 2898,0 \\
\hline
\end{tabular}

*Джерело: складено автором на основі даних [10, 11].

Як відомо, ВВП держави створює підприємницький сектор. $\mathrm{У}$ нашій країні нараховується значно менша кількість підприємств на 1000 осіб населення, через що існує значно менша кількість громадських організацій на 10000 осіб населення. Очевидно, що розвиток підприємницького сектору в державі - це передумова розвитку громадянського суспільства, i навпаки. $\mathrm{y}$ європейських та інших країнах із розвиненою економікою спостерігається достатньо висока кореспонденція між показниками кількості підприємств малого й середнього бізнесу (надалі МСБ) на 1000 осіб населення із показниками кількості громадських організацій на 10000 осіб населення, які також захищають інтереси підприємств малого бізнесу.

Показники, що характеризують стан розвитку підприємств МСБ та громадських організацій у різних країнах в 2020 p.

\begin{tabular}{|l|l|l|l|l|l|}
\hline Країни & $\begin{array}{l}\text { Кількість } \\
\text { підприємств } \\
\text { МСБ на 1000 } \\
\text { осіб населення }\end{array}$ & $\begin{array}{l}\text { Частка малих } \\
\text { підприємств у } \\
\text { ВВП, \% }\end{array}$ & $\begin{array}{l}\text { Частка малих } \\
\text { підприємств у } \\
\text { загальній } \\
\text { кількості } \\
\text { зайнятих, } \%\end{array}$ & $\begin{array}{l}\text { Кількість } \\
\text { громадських } \\
\text { організацій на } \\
10 \text { 000 осіб } \\
\text { населення }\end{array}$ & $\begin{array}{l}\text { Залученість громадян } \\
\text { до діяльності } \\
\text { громадських } \\
\text { організацій, \% }\end{array}$ \\
\hline Україна & 40 & $16 \%$ & $30 \%$ & 12 & $7.5 \%$ \\
\hline $\begin{array}{l}\text { Країни } \\
\text { члени } \\
\text { загалом })\end{array}$ & 74 & $58 \%$ & $67 \%$ & 32 & $14.5 \%$ \\
\hline США & 89 & $47 \%$ & $54 \%$ & 28 & $13 \%$ \\
\hline Канада & 115 & $70 \%$ & $63 \%$ & 36 & $16 \%$ \\
\hline Японія & 136 & $53 \%$ & $70 \%$ & 32 & $12,5 \%$ \\
\hline
\end{tabular}

*Джерело: складено автором на основі даних [10, 11].

Підприємницький сектор країни - це сукупність усіх малих (у т. ч. мікро-), середніх і великих підприємств різних форм власності, способів утворення та галузевої належності. У країнах із розвиненою економікою малий бізнес (до 50 осіб зайнятих), становить $90-95 \%$ від загальної чисельності всіх підприємств, 3 яких мікропідприємства (до 10 осіб зайнятих) близько $80 \%$, середній же бізнес (до 250 осіб зайнятих) - близько 5-7\%. У сукупності цей сектор створює від 50\% і більше ВВП держави та забезпечує до $70 \%$ зайнятості трудових ресурсів [7]. 
Важливе значення має також розвиток великого бізнесу (понад 250 осіб зайнятих), але господарювання. При цьому потрібно створити умови для появи якомога більшої кількості міноритарних (малих) акціонерів. У багатьох країнах iз розвиненою економікою вони становлять понад 50\% населення [4]. Не можна допускати виникнення ситуації, коли 1-3\% населення володіють близько 90\% національного багатства. Великий бізнес ні в якому разі не варто розглядати з позиції альтернативи малому бізнесу, оскільки вони виконують різні, посвоєму важливі функції в економіці держави i системі соціально-економічних відносин. Більше того, через різні форми кооперації на взаємовигідній основі можлива співпраця між ними, в результаті якої вони взаємодоповнюють один одного.

Розвиток підприємництва у країні залежить від багатьох факторів, серед яких: існуюча політична ситуація, макроекономічне середовище, кон'юнктура на світових зовнішніх ринках, соціальні умови, НТП, демографічний фактор, екологічна ситуація (стан навколишнього середовища), система оподаткування, адміністративно-дозвільна система, сформованість i розвиненість інститутів правової системи, рівень корупції, рівень монополізму в економіці, регуляторна політика, розвиненість системи транспортних, інформаційних й інших соціальних комунікацій, інфраструктура підприємництва (консалтингові та інформаційні центри, виставкові й ярмаркові комплекси, біржі, торгові доми, логістичні центри, бізнесінкубатори, коворкінги, бізнес-акселератори, підприємницькі хаби, кластери, технопарки, центри трансферту технологій тощо), ефективність фінансово-кредитного сектору i банківської системи, наявність програм інституціональної та фінансової підтримки підприємницького сектору, і насамперед ментальність, культура, освіта, наука, релігія, історична пам'ять, звичаї та ін.

Якщо апелювати до економічної науки, то економічні школи, що виникли на різних етапах історичної еволюції, висувають різні концепції та роблять акцент на різних факторах, які, на їхню думку, більше чи менше впливають на розвиток підприємницького сектору.

Так, класики від часів А. Сміта, Д. Рікардо і Д. С. Мілля та їхні послідовники (представники школи маржиналізму) вважають, що умова розвитку підприємництва й економіки загалом це насамперед захист права приватної власності та вільної конкуренції, а ринковий механізм саморегулювання здатний автоматично на принципах конкуренціі, демонополізації (деолігархізації) й розвитку акціонерних форм забезпечити ефективність економічної системи. Ліберальні ідеї, зокрема ідея ефективності саморегулювання, зазнають гострої критики 3 боку розробників марксистської теорії й меншою мірою 3 боку представників історичної школи політекономії. Представники кейнсіанської школи політекономії стверджують, що ключовим фактором розвитку підприємництва $є$ ефективне державне регулювання шляхом постійного стимулювання сукупного попиту, який спонукає бізнес більше виробляти. Представники ж теорії економіки пропозиції більше звертають увагу на необхідність стимулювання сукупної пропозиції шляхом зменшення ставок оподаткування, оскільки стимулювання тільки попиту може провокувати інфляційні та девальваційні процеси, зростання дефіциту бюджету, державного боргу й ін. На важливості одночасного стимулювання як попиту, так i пропозиції 3 урахуванням стану економіки, часових періодів та зайнятості ресурсів наголошує школа неокласичного синтезу. Як основний фактор розвитку підприємницького сектору й ефективності економічної системи загалом слід розглядати створення сприятливих умов для розвитку малого бізнесу й впровадження ним інновацій - такої позиції дотримується Й. А. Шумпетер (школа шумпетеріанства). Школа ордолібералізму ключовим фактором, що впливає на розвиток підприємництва у країні, визначає демонополізацію економіки та створення конкурентного середовища. На важливості ефективного індикативного планування в економіці, у тому числі щодо підприємництва, робить акцент школа дирижизму. Водночас школа монетаризму як ключовий фактор щодо розвитку бізнес-середовища розглядає необхідність забезпечення монетарної (насамперед цінової й валютно курсової) стабільності, але розвиток підприємницького сектору i конкуренції - одна 3 невід'ємних важливих умов забезпечення монетарної стабільності. Необхідність зменшення трансакційних витрат для підприємницького сектору як плати за користування ринком (дебюрократизаціi) обгрунтовує школа неоінституціоналізму. Важливість якомога меншого втручання держави в економіку та діяльність бізнесу підтверджують теорія економічного лібералізму Ф. Хайєка і теорія раціональних очікувань. Школа інституціоналізму наголошує на необхідності дослідження впливу інституційного середовища 
(правової системи, освіти, науки, НТП тощо) та його еволюції на підприємницький сектор, економічну систему і дію ринкового механізму. Представники нової інституціональної економічної теорії вважають, що визначальний вплив на підприємницький сектор та економіку мають різні формальні й неформальні інститути, насамперед: культура, ментальність, звичаї, традиції, історична пам'ять тощо (як стверджує Д. Норт, історія показує, що культура, ідеї та ідеології мають значення [9]). Теорія поведінкової економіки (біхевіоризм) доводить, що психологічні й емоційні фактори впливають на прийняття рішень у сфері бізнесу і розвиток підприємницького сектору й економічну ситуацію загалом.

Інтерпретуючи останні тренди і здобутки в економічній науці, зазначимо, що для створення власного бізнесу майбутнім підприємцям потрібно до цього бути готовими культурно, ментально, світоглядно й психологічно.

Наголосимо, що надважливий ресурс для економіки - це підприємницькі здібності (підприємницький хист) людей. За даними статистики, у світі лише $5 \%$ населення займається підприємницькою діяльністю [11], але при цьому спостерігається значна регіональна диференціація між країнами. Потрібно визнати, що наша держава за показниками розвитку підприємництва поступається країнам із розвиненою економікою. Проте якщо Україна ставить за мету наблизитись за рівнем соціально-економічного розвитку до провідних країн світу, насамперед до країнчленів $\mathrm{CC}$, то дуже важливо забезпечити зростання кількості населення, яке займається підприємницькою діяльністю. При цьому виникає запитання: де шукати такий бізнес, стартерів (новостворені компанії), стартаперів (інноваційні новостворені компанії) та відповідно осіб 3 підприємницькими здібностями? Зокрема, міжнародна статистика показує, що середній вік людини, яка створює новий бізнес, становить 25 років.

Однозначно можемо стверджувати, що для появи якомога більшої кількості людей, які створюють власний бізнес, необхідно проводити:

a) їхнє навчання цього (для нашої країни на сучасному етапі розвитку це можна порівняти 3 впливом поширення книжності на соціальноекономічний розвиток у Київській Русі в ХІ ст.);

б) їхню підготовку до цього ментально (в перекладі 3 латинської мови «mentos» означає «мислення»), світоглядно і культурно.

В Україні досі не розроблено дієвих освітніх, інкубаційних, акселераційних та інших програм, спрямованих на підтримку i популяризацію підприємницької культури. Відповідно, вітчизняний бізнес - це: а) результат діяльності людей 3 підприємницькими здібностями (самородки); б) наслідок порушення законодавства держави, у т. ч. кримінального чи корупційного характеру; в) умова виживання (торгівля на ринку й ін.). Проте нашій країні потрібно швидкими темпами пройти етап «дикого капіталізму». В Україні необхідно створити умови для формування соціально відповідального та інноваційно активного власного мікро-, малого і середнього бізнесу. Власне кажучи, у цьому мають полягати український економічний націоналізм та одна 3 основних стратегічних цілей i візій нашої держави. Адже для багатьох успішних компаній різних країн, у т. ч. відомих європейських i світових брендів, $є$ цінністю розвиток економіки своєї країни та їхня належність до неї.

у сучасному світі закономірність виявляється у тому, що національний бізнес може бути достатньо ефективним, а економічний розвиток держави - сталим, тільки за умови, якщо підприємницький сектор:

а) інноваційно активний;

б) соціально відповідальний.

Узагалі ці два складники формування успішного бренда окремої компанії впровадження нею інновацій (бренди створюються на основі інновацій) та інтеграція соціальних, екологічних і культурних проблем у комерційну діяльність - треба вважати основними. Успішно сформований бренд компанії - це впізнаваність на ринку, а отже - іiі продажі й відповідно, прибутки (як відомо, до $80 \%$ всіх товарів і послуг на ринку реалізують відомі бренди).

$\mathrm{y}$ країнах із розвиненою економікою близько $70 \%$ від усіх підприємств, насамперед малого (у т. ч. мікро-) і середнього бізнесу, інноваційно активні [5]. До 50\% нововведень створюються та реалізуються саме у цьому секторі. Згідно із Законом України «Про інноваційну діяльність», інноваційне підприємство визначається як підприємство (об'єднання підприємств), що розробляє, виробляє і реалізує інноваційні продукти і (або) продукцію чи послуги, обсяг яких у грошовому вимірі перевищує 70 відсотків загального обсягу продукції та (або) послуг [1]. Відповідно до Наказу Державного комітету статистики України «Про затвердження форм державних статистичних спостережень 3 статистики науково-технічного прогресу», інноваційно активними $€$ ті підприємства, які здійснювали інновації протягом останніх трьох років [5]. 
Щодо офіційної статистичної інформації, яка стосується інноваційної активності та діяльності сектору малого бізнесу, то вона в Україні не обліковується. Надалі для оперативного відстеження ефективності цього економічного сектору і визначення ступеня його впливу на макроекономічні показники країни доцільно запровадити щоквартальний моніторинг інноваційної активності малого бізнесу, за його результатами публікувати щорічний звіт, і змінити процедури статистичної звітності суб'єктів малого бізнесу на основі перегляду порядку ведення аналітичного обліку.

Загалом 3 точки зору відношення до інноваційної діяльності сектор малого підприємництва (інноваційно активний малий бізнес) не є абсолютно однорідним і складається 3 трьох різних груп малих фірм, які суттєво відрізняються за регулярністю і метою ведення інноваційної діяльності.

Першу групу формують традиційні малі фірми, що працюють у різних галузях i під тиском ринкової конкуренції змушені ситуативно чи періодично впроваджувати інновації. Роль в інноваційному процесі цієї групи малих фірм, як правило, обмежується участю у дифузії інновацій або ситуативним, нецілеспрямованим винайденням і поширенням удосконалювальних інновацій.

Так, до другої групи входять науководослідні малі фірми, які професійно займаються діяльністю у сфері досліджень та розробок переважно на замовлення ринкових агентів, великого бізнесу або державних установ. До таких структур належать: приватні науководослідні фірми, інститути, лабораторії, що діють на комерційній основі й відповідають законодавчо встановленим критеріям належності до сектору малого підприємництва. Малі фірми цієї групи $\epsilon$ головними постачальниками новаторських ідей.

До третьої групи зараховують інноваційно зорієнтовані малі фірми, тобто ті, діяльність яких зосереджена на реалізації здебільшого власної новаторської ідеї. Інноваційна діяльність цієї групи малих фірм полягає у самостійній розробці, комерціалізації та використанні новацій. Інноваційна діяльність має стратегічне значення для інноваційно орієнтованих малих фірм, і від успішності ऑii ведення повністю залежать їхня прибутковість і перспективи зростання.

Високоефективна, зорієнтована на інновації економіка, характерна ознака якої виявляється в наявності великої кількості інноваційно активних підприємств, може забезпечити більш високі темпи економічного зростання, що переважно супроводжуються збільшенням продуктивності праці, зменшенням енергоємності й матеріаломісткості та підвищенням конкурентоспроможності. Незважаючи на наявність відповідних спеціальних програм стимулювання інноваційного розвитку й економічних стимулів щодо здійснення інвестиційно-інноваційної діяльності суб'єктами господарювання, одна з основних причин такого високого рівня інноваційної активності підприємств у країнах з розвиненою економікою полягає у тому, що це умова: а) їхнього виживання в умовах конкуренції; б) їхньої можливості щодо розширення сегмента збуту власної продукції та послуг, освоєння нових ринків і отримання більших прибутків.

Не менш важливе значення для економіки має наявність великої кількості соціально відповідальних підприємств. Так, у європейських та інших країнах із розвиненою соціально зорієнтованою ринковою економікою кількість соціально відповідальних підприємств, у т. ч. (насамперед) підприємств мікро-, малого і середнього бізнесу, становить близько $80 \%$ від їхньої загальної чисельності [12]. В Україні ж $з$ огляду на існуючі соціально-економічні умови та відповідно до того, які сформувались правила й етичні норми щодо ведення бізнесу, цей показник значно нижчі. Згідно 3 прийнятими міжнародними стандартами, соціальна відповідальність бізнесу - це відповідальне ставлення компанії до свого продукту або послуги, споживачів, найманих працівників, партнерів і конкурентів, активна соціальна позиція, участь у розв'язанні різних соціальних проблем, відповідність діяльності компанії законам та міжнародним правилам поведінки і т. iн. Відповідно до визначення Європейської Комісії, за суттю це інтеграція компанією гуманітарних, соціальних, культурних та екологічних проблем у свою комерційну діяльність на добровільній основі.

На цьому етапі розвитку суспільних відносин бути соціально відповідальним означає мати додаткові конкурентні переваги. Поліпшення іміджу i репутації компанії - це важливий елемент iї маркетингової політики та інвестиція у формування власного бренда. Очевидно, що для суспільства вигідно, коли бізнес законослухняний (діє в межах правового поля), сплачує податки, створює робочі місця (у т. ч. для осіб 3 особливими потребами), проводить благодійну діяльність, бере активну участь у розвитку громад i територій та підтримці різних суспільних, гуманітарних, 
культурних, освітніх, наукових, медичних, спортивних, екологічних, інфраструктурних, логістичних та інших проєктів. Від соціальних інвестицій одержує переваги як економіка держави, так і підприємницький сектор. Якщо ж розглянути цю проблему 3 позицій стратегії ведення бізнесу, то можна констатувати, що у довгостроковому періоді компанія не стане успішною, не будучи соціально відповідальною.

3 огляду на те, що основою економічного розвитку будь-якої країни $є$ соціально відповідальний та інноваційно активний власний мікро-, малий і середній бізнес, для нашої держави особливої актуальності набуває проблема активізації появи якомога більшої кількості таких суб'єктів господарювання незалежно від галузевої належності (сфери наукомістких послуг, IT-технологій, промислового й аграрного секторів, будівництва, туризму, торгівлі й ін.).

Це насамперед потребує вжиття комплексу таких заходів:

1. Ініціювати впровадження в усі освітні заклади II-IV рівнів акредитації (у т. ч. шкільної освіти) обов'язкового курсу (дисципліни) «Організація власного бізнесу» («Фінансування та організація власного бізнесу») за участю фахівців-практиків і науковців.

Метою такого курсу $є$ : популяризація підприємницької культури серед молоді, підготовка студентів до реалізації власних бізнес-ідей, формування дієвих фахівців, готових до практичної діяльності, підвищення ефективності зв'язку в системі освіта-наукабізнес, позиціонування країни та їі регіонів як лідерів у розвитку малого і середнього бізнесу в перспективі. Цей курс передбачає: розгляд прикладів з історії створення успішного бізнесу, вивчення проблем, пов'язаних із логістикою започаткування власного бізнесу, бізнесплануванням, особливостями менеджменту та маркетингу в малому бізнесі, джерелами його фінансування й ін. Підсумковий модульконтроль полягатиме в обговоренні та захисті власних бізнес-ідей, основними критеріями щодо яких мають бути: відповідність параметрам малого бізнесу, реалістичність упровадження, інноваційність і соціальна відповідальність бізнесу.

Так, міжнародна статистика показує, 70\% всіх бізнес-ідей не реалізовуються, але важливо створити умови для виникнення таких ідей i зростання їхньої кількості [13]. Появі ефективно функціонуючого бізнесу передує виникнення новостворених компаній (бізнес-стартерів і стартапів), а відповідно їхньому формуванню - народження бізнес-ідей, насамперед у молодіжному середовищі.

2. Пропонувати створення 3 ініціативи навчальних закладів, органів влади та громадського сектору мереж бізнес-інкубаціі, бізнес-акселерації, бізнес-центрів, коворкінгів, кластерів та інших елементів інфраструктури підприємництва. Водночас для народжених бізнес-ідей потрібно створити сприятливі «тепличні» умови i забезпечити відповідний сервіс (тренінги, семінари, постійні зустрічі 3 менторами, фахівцями-практиками й успішними підприємцями, консультації 3 питань бізнеспланування, маркетингу, обліку та оподаткування, правового забезпечення діяльності бізнесу, налагодження комунікацій із грантрайтерами, інвесторами, «бізнес-ангелами» i фінансово-кредитними установами, створення атмосфери співробітництва (колаборації) та партнерства, яка сприятиме підготовці до здійснення бізнес-проекту, й ін.) $з$ метою їхньої реалізації в майбутньому.

3. Сприяти розробці та впровадженню програми ефективної фінансової підтримки сектору малого бізнесу, а саме мікрокредитування бізнес-стартерів та стартапів, i розвивати систему альтернативних джерел фінансування (гранти, інвестиційні форуми стартапів, краудфандинг, венчурне фінансування й ін.).

Реалізація будь-якого бізнес-проєкту передбачає наявність джерел для його фінансування. Їх умовно можна поділити на основні чотири групи:

- традиційні джерела фінансування бізнесу: власний капітал, банківські кредити, кошти, залучені від емісії цінних паперів, позики небанківських фінансово-кредитних установ та iн.;

- альтернативні (сучасні) джерела фінансування бізнесу: фандрейзинг, краудфандинг, краудлендинг, краудінвестинг, краудсорсинг, гранти (у т. ч. за рахунок міжнародних організацій) та ін.;

- залучення ресурсів шляхом використання різних форм фінансової кооперації підприємств: венчурне фінансування, лізинг, субпідряд, франчайзинг та ін.;

- залучення ресурсів шляхом використання різних форм державної фінансової підтримки малого бізнесу: програми мікрокредитування, створення фондів підтримки стартапів, організація інвестиційних форумів стартапів i ярмарків кредитів, дотації та субсидії бізнесу, державне замовлення, застосування механізму часткового відшкодування процентних ставок за кредитом та ін. 
Власний капітал у структурі джерел фінансування бізнесу становить близько 30\% [7]. 3 огляду на зростаючу роль інновацій і малого підприємництва у ринкових відносинах $\mathrm{i}$ структурі економіки держави надзвичайно важливе значення має створення сприятливих, у т. ч. пільгових умов для залучення бізнесом фінансових ресурсів. При цьому вагому роль відіграють такі фактори: низький рівень процентних ставок, розвиненість системи сучасних альтернативних джерел фінансування малого бізнесу, вдосконалення спектра фінансових продуктів i технологій. Від запровадження нових якісних фінансових послуг та покращення сервісу отримують вигоду як фінансово-кредитні установи за рахунок розширення бази перспективних клієнтів, так i сектор інноваційно активного та соціально відповідального малого бізнесу.

Висновки. На основі проведених досліджень i здійснених узагальнень можемо зробити такі висновки:

1. При реалізації економічної політики щодо стимулювання розвитку підприємницького сектору треба спиратись на напрацювання світової економічної науки. Науковці сучасності стверджують, що розвиток підприємницького сектору, як і економіки загалом, залежить від дії багатьох факторів, однак надзвичайно важливе значення має вплив таких інституцій: культура, освіта, наука, захист довкілля, ментальність, історична пам'ять, патріотичне виховання, розвиненість правової системи та ін. Саме це вказано в програмних документах авторитетних міжнародних організацій.

2. Без упровадження на фаховому рівні в усіх освітніх закладах (у школах, університетах й ін.) за участю фахівців-практиків і науковців курсу «Організація власного бізнесу», реалізації дієвих інкубаційних та акселераційних програм, створення інфраструктури підприємництва i виконання програми ефективної фінансової підтримки сектору малого бізнесу, бізнесстартерів та інноваційних стартапів забезпечити сталий соціально-економічний розвиток нашої держави неможливо. Хоч застосування таких інструментів на першому етапі призводить до незначних труднощів адміністративного i методичного характеру, вони не потребують значних бюджетних витрат. До того ж суспільна вигода очевидна й альтернативи використанню таких інструментів на сьогодні не існує.

3. Соціально відповідальний та інноваційно активний власний бізнес (зокрема, створення в суспільстві іміджу добропорядного і законослухняного підприємця) має становити основу формування бренда держави й регіонів. До інших важливих складників бренда, треба зарахувати вивчення культури і відповідно впровадження на фаховому рівні в освітній процес курсу «Основи культури (правова, управлінська, екологічна культура, мистецтвознавство та ін.) і патріотичне виховання», та апелювання до величних постатей i видатних звершень України у минулому й успішних історичних брендів (зокрема, державних традицій і культури Київської Русі, Королівства Русі та багатьох інших унікальних державних утворень). Адже бренд держави є тим психологічно-емоційним фактором, (у контексті інтерпретації теорії поведінкової економіки), який дасть змогу сприяти зміні ментальності народу як інституції, що позитивно вплине (в контексті інтерпретації нової інституціональної економічної теорії) на розвиток соціально відповідального й інноваційно активного власного бізнесу.

Саме розвиток у державі соціально відповідального та інноваційно активного власного малого бізнесу приведе до формування середнього класу i розвитку громадянського суспільства, а отже, вплине на формування ефективних формальних, у т. ч. державних інститутів, і неформальних інституцій (зокрема зміна ментальності). Водночас останне сприятиме розвитку і реалізації потенціалу соціально відповідального та інноваційно активного власного мікро-, малого й середнього бізнесу та поліпшенню добробуту людей.

\section{Список літератури}

1. Бабець І. Г., Полякова Ю. В., Мокій О. А. Обгрунтування напрямів розвитку інноваційного підприємництва 3 урахуванням світового досвіду. URL: http://niss.lviv.ua/analytics/65.htm. (дата звернення: 27.11.2020).

2. Бойчук Р. М., Гречаник Б. В. Формування інфраструктури інноваційного забезпечення розвитку малого бізнесу. URL: http://www.google.com.ua/url?url= http://www.pu.i

f.ua/ depart/ Finances/resource/file (дата звернення: 09.12.2020).

3. Васьківська К., Петрик I., Ярмольський С. Фінансово-економічний механізм розвитку мало- го підприємництва. Вісник ДАУ, 2013. №20. С. 135-140. URL: http://www.google.com.ua/url?url= http://www.pu.i f.ua/ depart/Finances/resource/file (дата звернення: 09.02.2021).

4. Дикань О.В. Розвиток малого бізнесу в Україні: проблеми та шляхи забезпечення. Вісник економіки 
транспорту і промисловості. Збір наук. праць. Харків, УкрДУЗТ, 2017. № 57. С. 58-66.

5. Камінчан Г. В. Інноваційна активність малого та середнього бізнесу в URL: http://www.google.com.ua/url?url=http://oaji.net/ar ticles/ 2015/7971426331821.pdf\&rct=j\&q=\&esrc $=$ s\&sa $=$ U\&ved=0ahUKEwjVnerb447NAhWJ3SwKHSxgDw4QF ggVMAA\&usg=AFQjCNFasmY4vqmpC9840dgyVYeW umXCMA (дата звернення: 17.01.2021).

6. Калініченко Л., Кобзистий С. Актуальні проблеми фінансування підприємств малого та середнього бізнесу в сучасних умовах. Економічний форум. 2013. № 2. С. 1-8.

7. Касьян О.Ю. Фінансування малого бізнесу в Україні: проблеми та можливості розширення. Управління розвитком. 2013. № 5. С. 85-87.

8. Компанієць В.В. Чинники формування та стимулювання соціально відповідальної поведінки особистості, бізнесу, суспільства, держави в Україні. Вісник економічної науки України. 2013. № 2(24). С. 30-36.
9. Норт Д. Інституції, інституційна зміна та функціонування економіки.: Основи, 2000. 198 с.

10. Офіційний сайт Державної служби статистики України. URL: http://www.ukrstat.gov.ua (дата звернення: 02.03.2021).

11. Офіційний сайт Eurostat. URL: https://ec.europa.eu/eurostat/home (дата звернення: 02.03.2021).

12. Полякова О. М., Хорошаєва Є.В. Соціальна відповідальність малого бізнесу як його конкурентна перевага. Вісник економіки транспорту i промисловості. 2017. №60. URL: http:// btie.kart.edu.ua /article /view File/121148/116144 (дата звернення: 23.02.2021).

13. Ступко А. В. Інноваційна активність малого бізнесу в регіонах України Ефективна економіка. 2010 . №3. URL: http://www.economy.nayka.com.ua/?op=1\&z=155 (дата звернення 21.02.2021).

\section{References}

1. Babets' I. H., Polyakova YU. V., Mokiy O. A. Obgruntuvannya napryamiv rozvytku innovatsiynoho pidpryyemnytstva $\mathrm{z}$ urakhuvannyam svitovoho dosvidu [The substantiation of development directions of innovative business taking into account the world experience]. Available at: http://niss.lviv.ua/analytics/65.htm (accessed 27 November 2020).

2. Boychuk R. M., Hrechanyk B. V. Formuvannya infrastruktury innovatsiynoho zabezpechennya rozvytku maloho biznesu [Formation of infrastructure for innovative support of small business development]. Available at: http://www.google.com.ua/url?url= http://www.pu.if.ua/ depart/ Finances/resource/file (accessed 9 December 2020).

3. Vas'kivs'ka K., Petryk I., Yarmol's'kyy S. (2013) Finansovo-ekonomichnyy mekhanizm rozvytku maloho pidpryyemnytstva [Financial and economic mechanism of small business development]. Visnyk DAU [Bulletin of DAU], no. 20, pp. 135-140. Available at: http://www.google.com.ua/url?url= http://www.pu.if.ua/ depart/Finances/resource/file (accessed 9 February 2021).

4. Dykan' O.V. (2017) Rozvytok maloho biznesu v Ukrayini: problemy ta shlyakhy zabezpechennya [Small business development in Ukraine: problems and ways to support]. Visnyk ekonomiky transportu i promyslovosti [Bulletin of Transport Economics and Industry], no. 57, pp. 58-66.

5. Kaminchan H. V. Innovatsiyna aktyvnist' maloho ta seredn'oho biznesu v Ukrayini [Innovative activity of small and medium business in Ukraine]. Available at: http://www.google.com.ua/url?url=http://oaji.net/articles/ 2015/7971426331821.pdf\&rct $=\mathrm{j} \& \mathrm{q}=\&$ esrc $=$ s\&sa $=$ U\&ved $=0$ ahUKEwjVnerb447NAhWJ3SwKHSxgDw4QFggVM AA\&usg=AFQjCNFasmY4vqmpC9840dgyVYeWumXC MA (accessed 17 January 2021).

6. Kalinichenko L., Kobzystyy S. (2013) Aktual'ni problemy finansuvannya pidpryyemstv maloho ta seredn'oho biznesu V suchasnykh umovakh [Actual problems of financing of small and medium business enterprises in modern conditions]. Ekonomichnyy forum [Economic forum], no. 2, pp. 1-8.

7. Kas'yan O.YU. (2013) Finansuvannya maloho biznesu V Ukrayini: problemy ta mozhlyvosti rozshyrennya [Small business financing in Ukraine: problems and opportunities for expansion]. Upravlinnya rozvytkom [Development management], no. 5, pp. 85-87.

8. Kompaniyets' V.V. (2013) Chynnyky formuvannya ta stymulyuvannya sotsial'no vidpovidal'noyi povedinky osobystosti, biznesu, suspil'stva, derzhavy v Ukrayini [Factors of formation and stimulation of socially responsible behavior of the person, business, society, the state in Ukraine]. Visnyk ekonomichnoyi nauky Ukrayiny [Bulletin of Economic Science of Ukraine], vol. 24, no. 2, pp. 30-36.

9. Nort D. (2000) Instytutsii, instytutsiina zmina ta funktsionuvannia ekonomiky [Institutions, institutional change and functioning of the economy]. Kyiv: Osnovy. (in Ukrainian).

10. Official site of the State Statistics Service of Ukraine. Available at: http://www.ukrstat.gov.ua (accessed 2 March 2021).

11. Official site of Eurostat. Available at: https:/ec.europa.eu/eurostat/home (accessed 2 March 2021).

12. Polyakova O. M., Khoroshayeva YE.V. (2017) Sotsial'na vidpovidal'nist' maloho biznesu yak yoho konkurentna perevaha [Social responsibility of small business as its competitive advantage]. Visnyk ekonomiky transportu i promyslovosti [Bulletin of Transport Economics and Industry]. Available at: http:// btie.kart.edu.ua /article /view File/121148/116144 (accessed 23 February 2021).

13. Stupko A. V. (2010) Innovatsiyna aktyvnist' maloho biznesu $\mathrm{v}$ rehionakh Ukrayiny [Innovative activity of small business in the regions of Ukraine]. Efektyvna ekonomika [Efficient economy]. Available at: http://www.economy.nayka.com.ua/?op=1\&z=155 (accessed 21 February 2021). 


\section{Аннотация \\ Евгений Ткач, Сергей Ткач \\ СОЦИАЛЬНО ОТВЕТСТВЕННЫЙ И ИННОВАЦИОННО АКТИВНЫЙ СОБСТВЕННЫЙ МИКРО-, МАЛЫЙ И СРЕДНИЙ БИЗНЕС КАК ОСНОВА ЭКОНОМИЧЕСКОГО РАЗВИТИЯ}

Осуществлено исследование влияния соииально ответственного и инноващионно активного собственного микро-, малого и среднего бизнеса на развитие экономики, становление гражданского общества $и$ благосостояние людей. Отмечено, что национальный бизнес может быть достаточно эффективным, а экономическое развитие государства - постоянным, только при условии, если предпринимательский сектор является: а) инновационно активным; б) социально ответственным.

Ключевые слова: собственный микро-, малый и средний бизнес, инновачионно активный бизнес, соииально ответственный бизнес, неформальные институты, ментальность, бизнес-идея, стартап, учебный курс, инфраструктура предпринимательства, финансирование бизнеса.

Summary

Yevhen Tkach, Serhii Tkach

\section{SOCIALLY RESPONSIBLE AND INNOVATIVELY ACTIVE MICRO, SMALL AND MEDIUM OWN BUSINESS AS THE BASIS OF ECONOMIC DEVELOPMENT}

The article is devoted to the study and analysis of the impact of socially responsible and innovatively active micro, small and medium own business on the development of the economy, civil society and human well-being. It is noted that the national business can be quite effective, and therefore sustainable economic development of the state, only if the business sector is: a) innovative, b) socially responsible.

According to economics, it is obvious that the formation of effective formal and informal institutions (for example, a change of mentality) has a significant impact on the development of entrepreneurship. Given the fact that in our country there is a deficit of such a vital resource for the economy as entrepreneurial skills, and the average age of a person starting a new business is 25 years, it is determined that in order to have as many people starting their own business, it is needed to teach it and prepare for it mentally and culturally.

It is noted that it is necessary in all educational institutions (schools, universities, etc.) to implement, with the participation of practitioners and scientists, the course (discipline) "Organization of own business", realization effective incubation and acceleration programs, creating proper business infrastructure. It is needed also to implement the effective financial support programs for the small business sector, first of all: microcredits for business starters and startups, development of alternative financial sources system - grants, investment forums of startups, crowdfunding, venture financing, etc.

Keywords: micro, small and medium own business, innovatively active business, socially responsible business, informal institutions, mentality, business idea, startup, educational course, business infrastructure, business financing. 